\title{
Antioxidant Activities in Sweet Potatoes Leaves Steamed with Spices
}

\author{
Edith A. Agbo ${ }^{1}$, Konan Kouassi ${ }^{2}$, Désirée A. Gouekou ${ }^{1}$, Souleymane Méité ${ }^{3}$, Albarin G. Gbogouri ${ }^{1} \&$ Kouakou \\ Brou $^{1}$ \\ ${ }^{1}$ Nutrition and Food Security Laboratory, Food Science Department, Nangui Abrogoua University, Abidjan, Côte \\ d'Ivoire \\ ${ }^{2}$ Biochemical Pharmacodynamics Laboratory, Félix Houphouët Boigny University, Côte d'Ivoire \\ ${ }^{3}$ Clinical Unit of Toxicology, Phytochemistry and Metabolomics, Basic Biochemistry Department, Pasteur \\ Institute of Côte d'Ivoire, Abidjan, Côte d'Ivoire
}

Correspondence: Adouko Edith Agbo, Nutrition and Food Security Laboratory, Food Science Department, Nangui Abrogoua University, Abidjan, Côte d’Ivoire. Tel: 225-0779-0364. E-mail: edipagbo@gmail.com

\author{
Received: May 4, $2020 \quad$ Accepted: June 11, $2020 \quad$ Online Published: July 7, 2020 \\ doi:10.5539/jfr.v9n4p41 URL: https://doi.org/10.5539/jfr.v9n4p41
}

\begin{abstract}
Sweet potato leaves contain phenolic and flavonoids compounds which give them a potential antioxidant capacity. However, these antioxidant activities can be lost during cooking due to high temperature. In the aim to enhance their antioxidant activities, sweet potato leaves were steamed with antioxidant spices. The spices were used alone or mixed: nutmeg, Guinea pepper, cloves, nutmeg-Guinea pepper, nutmeg-cloves, Guinea pepper-cloves and nutmeg-Guinea pepper-cloves. The phytochemical analysis was carried-out on total phenolic compounds and flavonoids, while the antioxidant activities were determined via free radical-scavenging and inhibition power of lipid peroxidation. The results showed that cloves total phenolic content $(513.33 \mathrm{mg}$ Gallic Acid Equivalent (GAE)/g dry matter (DM)) increased to $1786.67 \mathrm{mg} \mathrm{GAE} / \mathrm{g}$ DM when mixed with Guinea pepper. Flavonoids content was high in Guinea pepper-cloves (57.17 mg Quercetin Equivalent (QE)/g DM). In sweet potato steamed leaves, total phenolic compounds content is improved by incorporating cloves $(625.83 \mathrm{mg}$ GAE/g DM), while flavonoids content is slightly improved by Guinea pepper (125.00 mg QE/g DM). Among spices, cloves, Guinea pepper-cloves and nutmeg $\mathrm{IC}_{50}$ values $(0.45,0.83$ and $1.50 \mu \mathrm{g} / \mathrm{ml}$ respectively) did not differ significantly to that of vitamin $\mathrm{C}(1.67 \mu \mathrm{g} / \mathrm{ml})$, indicating that they had a good antiradical activity. The capacity of spices and steamed sweet potato leaves with and without spices to inhibit lipid peroxidation was higher than that of Gallic acid which is the standard reference. Spices, particularly cloves and Guinea pepper can improve antioxidant activities during sweet potato leaves steaming.
\end{abstract}

Keywords: antioxidant activities, lipid peroxidation, spices, steaming, sweet potato leaves.

\section{Introduction}

Sweet potato leaves are the most consumed leafy vegetables in Côte d'Ivoire (Agbo et al., 2014). As the other vegetables, they are recommended to human organism well-being because they contain high levels of vitamins, minerals, fiber, and phenolic compounds. Indeed, they are consumed for their capacities to contribute to overcome anemia and other nutrients deficiencies (Vyas et al., 2009; Gerla \& Pietrzak, 2014). But sweet potato leaves are consumed after cooking. However, cooking occurs nutrients and phenolic compounds losses which increase with cooking time (Gokoglu et al., 2004; Chuah et al., 2008).

Leafy vegetables are also cooked with spices to improve their taste and their flavor. Moreover, spices contain phenolic compounds which give them a potential antioxidant activity (Shobana \& Naidu, 2000). Such properties could be used to prevent micronutrients losses and increase food antioxidant capacities to overcome oxidative stress due to free radicals (García-Alonso et al., 2004). Indeed, Gayathri et al. (2004), in their studies, have shown that cooking vegetables with acidulate and antioxidant spices (tamarind, turmeric and onion) increase the retention of $\beta$-carotene in vegetables but they not focused on antioxidant activities. Therefore, it is opportune to appreciate spices impact on potential antioxidant activities in sweet potato leaves during cooking.

Several studies have been conducted on fresh and cooked sweet potato leaves. Some of them revealed important antioxidant activities in fresh leaves (Mibei et al., 2012; Agbo et al., 2018). Johnson and Pace (2010) have also shown a high level of radical scavenging activity in sweet potato leaves in comparison to the other parts of the 
plant. However, there were important losses while cooking leaves with water (Zoro et al., 2014; Agbo et al., 2019). Therefore, steaming seemed to be an appropriate cooking method. Indeed, Johnson and Pace (2010) indicated that blanching of sweet potato leaves for $60 \mathrm{~s}$ resulted in increased flavonoids retention with level like those in fresh leaves and Tang et al. (2015) also revealed that steaming was good for the retention of total phenolic compound. But these studies have not determined the possible effect of spices on antioxidant activities in the leaves. This study was conducted to evaluate the potential antioxidant activities in sweet potato leaves steamed with antioxidant spices (cloves, nutmeg, and Guinea pepper).

\section{Instrumentations}

The laboratory instrument used were an orbital shaker incubator (BJPX-Kansas) from Biobase Biodustry (Shandong) Co. Ltd (Shandong, China) and a spectrophotometer (UV-1800) from Beijing Rayleigh analytical instrument Co., Ltd (Beijing, China). The water bath (SWB-A) and the drying-oven (BOV-T70C) were from Biobase Meihua Trading Co., Ltd (Shandong, China).

\section{Chemicals and Reagents}

Chemicals reagents: methanol (CAS 67-56-1), ethanol (CAS 64-17-5), aluminium chlorure (CAS 7446-70-0), Folin-Ciocalteu reagent (CAS 5995-86-8), 2-diohenyl-1-picryhydrazyl (DPPH) (CAS 1898-66-4), were purchased from Sigma-Aldrich (St- Louis, MO, USA). Sodium carbonate (CAS 497-19-8), vitamin C (CAS 50-81-7), potassium acetate (CAS 127-08-2), ammonium thiocyanate (CAS 1762-95-4), were purchased from VWR Prolabo Chemicals (Leuven, Belgium). Gallic acid (CAS 149-91-7), quercetin (CAS 6151-25-3), linoleic acid (CAS 60-33-3) and iron II sulfate (CAS 7720-63-0) were purchased from Merk KGaA, 64271 (Darmstadt, Germany). All chemicals were analytical grade.

\section{Materials and Methods}

\subsection{Sample Collection}

Sweet potato leaves were collected in «Gouro Market» a leafy vegetables wholesale trade in Abidjan, Côte d'Ivoire. Cloves and nutmeg were also collected in the same market while Guinea pepper was harvested in a field in Dabou.

\subsection{Sampling Preparation}

Sweet potato leaves were collected from 3 sellers chosen randomly, then, mixed and transported to the laboratory for the analysis. The leaves were destalked, cleaned, washed under running water. Guinea pepper were burned before being dried under the sun for 1 week. Nutmeg was grated with a grater while Guinea pepper and cloves were ground with a grinder (Moulinex Lm 241025). Spices were used alone or mixed in the proportion of (1:1) for 2 spices or $(1: 1: 1)$ for 3 spices. The spices mixes were nutmeg-Guinea pepper, nutmeg-cloves, Guinea pepper-cloves and nutmeg-Guinea pepper-cloves.

\subsection{Steam Cooking}

The treatment used in this study was steaming. Sweet potato leaves were steamed for 20 minutes with a steam cooker (Severin DG 2438) without spices and with spices. A quantity of $600 \mathrm{~g}$ of leaves was used for each steaming. For steaming with spices, spices were mixed to fresh leaves before steaming process to the concentration of $1 \mathrm{~g}$ for $100 \mathrm{~g}$ of leaves. For all kind of samples, two steaming were performed. After steaming, all samples were dehydrated at $16^{\circ} \mathrm{C}$ during $72 \mathrm{~h}$ in a room under air conditioner.

\subsection{Analyses}

\subsubsection{Total Phenolic and Flavonoid Extraction and Determination}

Phenolic compounds were extracted according to Bala et al. (2014). Dried samples (10 g) were soaked in $100 \mathrm{ml}$ of methanol/water solution (80:20, v/v). The mixture was shaken with an orbital shaker incubator (BJPX-Kansas, Biobase) for 24 hours. After that, it was filtered with Whatman paper $n^{\circ} 1$ and the filtrate was stored in a drying-oven (BOV-T70C, Biobase) at $40^{\circ} \mathrm{C}$ during 24 hours for solvent evaporation. The final paste was the crude extract.

Total phenolic compounds were determined by Folin-Ciocalteu method at $765 \mathrm{~nm}$ and expressed as gallic acid equivalents (GAE) in milligrams per gram DM (Dry Matter) using the standard curve of gallic acid (Mc Donald et al., 2001). Total flavonoids were determined at $415 \mathrm{~nm}$ and expressed as quercetin equivalents (QE) in microgram per gram DM using the standard curve of quercetin (Chang et al., 2002).

\subsubsection{Free Radical Scavenging Activities and Anti-radical Power Determination}

Extracts free radical scavenging activities were measured based on DPPH method (Parejo et al., 2000). This test 
consists to evaluate the capacity of extract to fixed DPPH free radical by the measurement at $517 \mathrm{~nm}$. Vitamin C $(100 \mu \mathrm{g} / \mathrm{ml})$ was used as standard and the percent inhibitory activity was calculated as follow in equation 1 :

$$
\text { Inhibition DPPH (\%) }=\frac{\mathrm{Abs}_{\mathrm{c}}-\mathrm{Abs}_{\mathrm{e}}}{\mathrm{Abs}_{\mathrm{c}}} \times 100
$$

$\mathrm{Abs}_{\mathrm{c}}$ : absorbance of the control,

Abs $_{\mathrm{e}}$ : absorbance of the extract/standard.

The sample concentration which can inhibit $50 \%$ of DPPH $\left(\mathrm{IC}_{50}\right)$ was determined on graphic and allowed to calculate the efficient concentration $\left(\mathrm{EC}_{50}\right)$, which is the sample concentration which can reduce $1 \mu \mathrm{mol}$ of DPPH (Equation 2). The anti-radical power was then determined in equation 3 (Kroyer, 2004).

$$
\mathrm{EC}_{50}=\frac{\mathrm{IC}_{50}}{\mathrm{DPPH} \text { solution concentration (mg of sample / } \mu \mathrm{mol} \text { of reduced DPPH) }}
$$

$\mathrm{IC}_{50}$ : Sample concentration which inhibe $50 \%$ of DPPH

$\mathrm{EC}_{50}$ : Efficient concentration for $50 \%$ of DPPH

$$
\mathrm{ARP}=\frac{1}{\mathrm{EC}_{50}(\mu \mathrm{mol} \text { of reduced DPPH } / \mathrm{mg} \text { of sample })}
$$

ARP: anti-radical power

\subsubsection{Lipid Peroxidation Inhibitory Activity Determination}

Lipid peroxidation inhibitory activity was determined according to ammonium thiocyanate test with some slight modifications (Lee et al., 2009). A quantity of $0.5 \mathrm{ml}$ of samples extracts at graduate concentrations $(0.20$ to 6 $\mathrm{mg} / \mathrm{ml}$ ) was mixed to $0.20 \mathrm{ml}$ of linoleic acid $(20 \mathrm{mg} / \mathrm{ml}$ in ethanol $99 \%)$ and $0.40 \mathrm{ml}$ of phosphate buffer (50 $\mathrm{mM} ; \mathrm{pH}$ 7.4). The mixture was heated in a water bath at $40^{\circ} \mathrm{C}$ for $15 \mathrm{~min}$. Then, $0.10 \mathrm{ml}$ of mixture was added to the reaction mixture ( $3 \mathrm{ml}$ of ethanol $(70 \%), 0.10 \mathrm{ml}$ of ammonium thiocyanate $(30 \mathrm{mg} / \mathrm{ml})$ and $0.05 \mathrm{ml}$ of FeSO4 $(2.45 \mathrm{mg} / \mathrm{ml}$ in $\mathrm{HCl} 3.5 \%(\mathrm{v} / \mathrm{v}))$. The absorbance was determined at $500 \mathrm{~nm}$ after incubation at ambient temperature during $3 \mathrm{~min}$. Gallic acid $(100 \mu \mathrm{g} / \mathrm{ml})$ was used as standard. The inhibitory percentage of lipid peroxidation was calculated in equation 4 :

$$
\text { Lipid peroxidation inhibitory }(\%)=1-\frac{\mathrm{Abs}_{\mathrm{e}}}{\mathrm{Abs}_{\mathrm{c}}} \times 100
$$

$\mathrm{Abs}_{\mathrm{c}}$ : absorbance of the control,

Abs $_{\mathrm{e}}$ : absorbance of the extract/standard.

\subsubsection{Statistical Analysis}

Data analysis and graphic representations were made with Graph Pad Prism 5.00 (Microsoft U.S.A). Results made in triplicate were expressed as means with standard deviation. A one-way ANOVA was performed, and means were separated using Tukey test or Dunnett test $(\mathrm{p} \leq 0.05)$. For Dunnett test, samples were compared to vitamin $\mathrm{C}$ used as reference.

\section{Results \& Discussions}

\subsection{Total Phenolic and Flavonoid Compounds in Spices and Sweet Potato Leaves Steamed with and without Spices}

The study has evaluated the antioxidant activities in sweet potato leaves steamed with and without spices. Previously, total phenolic and flavonoids compounds have been determined in spices (alone or mixed). Total phenolic content is higher in cloves (513.33 mg GAE/g DM) than in nutmeg and Guinea pepper (Table 1). This corroborate Halvorsen et al. (2006) results which showed that cloves are on the top food products which have high antioxidant content due to phenolic compound. Moreover, Viuda-Martos et al. (2010) have revealed high phenolic content in cloves (898.89 mg GAE/g DM).

Among mixed spices, Guinea pepper-cloves have the most important total phenolic and flavonoids content which were about $1786.67 \mathrm{mg} \mathrm{GAE} / \mathrm{g} \mathrm{DM}$ and $57.17 \mathrm{mg}$ QE/g DM, respectively. However, total phenolic and flavonoids content are decreased in nutmeg-Guinea pepper, nutmeg-cloves, and nutmeg-Guinea pepper-cloves. According to Tangkanakul et al. (2009), Guinea pepper-cloves' total phenolic content is higher than that of turmeric which is about $1340.70 \mathrm{mg} \mathrm{GAE} / 100 \mathrm{~g}$. The fact that total phenolic and flavonoids content are increased 
in the mixe Guinea pepper-cloves suggest that Guinea pepper exhibit a positive synergistic effect over cloves. Such synergistic effect was also revealed by Shobana \& Naidu (2000) with the mixtures of onion-ginger and ginger-garlic. Moreover, the fact that in all mixes' spices containing nutmeg there is a decrease of total phenolic and flavonoids compounds suggest that nutmeg probably exhibit a negative synergetic effect over Guinea pepper and cloves.

Fresh sweet potato leaves contain important content of total phenolic and flavonoid compounds. The total phenolic content is higher than that indicated by Su et al. (2019) which is about $46.7 \mathrm{mg} \mathrm{GAE} / \mathrm{g}$ DM in Bonita (sweet potato leaves variety). According to Sun et al. (2014) polyphenols were very important in sweet potato leaves.

However, steaming process reduce total phenolic and flavonoid compounds. Among spices, only cloves improve total phenolic (625.83 mg GAE/g DM) content in steamed sweet potato leaves (Table 2). Flavonoids rate is slightly improved by the addition of Guinea pepper and cloves. This could be due to the total phenolic and flavonoids contained in these spices. It could be also due to the breakdown of tough cell walls during steaming process (Oboh \& Rocha, 2007). Moreover, Oulai et al. (2015) have revealed an increase of total phenolic during blanching from 15 to 45 minutes. Nutmeg and spices mixes containing nutmeg (nutmeg-Guinea pepper, nutmeg-cloves, and nutmeg-Guinea pepper-cloves) present lowest total phenolic compounds and flavonoids contents while added to sweet potato leaves during steaming. This is probably because these spices have low total phenolic and flavonoids content which may have inhibitory actions with other constituents of the plant.

Table 1. Total phenolic and flavonoid compounds content in spices (alone and mixed)

\begin{tabular}{lll}
\hline Spices & Total phenolic (mg GAE/g DM) & Flavonoid (mg QE/g DM) \\
\hline Nutmeg & $84.50 \pm 10.00^{\mathrm{b}}$ & $51.33 \pm 10.20^{\mathrm{b}}$ \\
Guinea pepper & $69.58 \pm 11.37^{\mathrm{a}}$ & $47.83 \pm 8.34^{\mathrm{b}}$ \\
Cloves & $513.33 \pm 49.64^{\mathrm{d}}$ & $42.67 \pm 3.88^{\mathrm{b}}$ \\
Nutmeg-Guinea pepper & $93.75 \pm 0.25^{\mathrm{b}}$ & $11.08 \pm 1.13^{\mathrm{a}}$ \\
Nutmeg-cloves & $223.75 \pm 1.30^{\mathrm{c}}$ & $14.00 \pm 1.09^{\mathrm{a}}$ \\
Guinea pepper-cloves & $1786.67 \pm 6.11^{\mathrm{e}}$ & $57.17 \pm 0.14^{\mathrm{c}}$ \\
Nutmeg-Guinea pepper-cloves & $140.92 \pm 0.38^{\mathrm{c}}$ & $10.67 \pm 1.23^{\mathrm{a}}$ \\
\hline
\end{tabular}

In row, values with different letter differed significantly (Tukey test, $\mathrm{p} \leq 0.05$ ).

Table 2. Total phenolic and flavonoid compounds content in sweet potatoes leaves steamed with and without spices

\begin{tabular}{lll}
\hline Sweet potatoes leaves & Total phenolic (mg GAE/g DM) & Flavonoid (mg QE/g DM) \\
\hline Fresh leaves & $1285.83 \pm 84.27^{\mathrm{d}}$ & $660.00 \pm 60.70^{\mathrm{d}}$ \\
Steamed leaves & $174.75 \pm 17.11^{\mathrm{b}}$ & $117.67 \pm 10.87^{\mathrm{c}}$ \\
Leaves nutmeg & $100.92 \pm 1.63^{\mathrm{a}}$ & $21.34 \pm 1.70^{\mathrm{a}}$ \\
Leaves Guinea pepper & $134.17 \pm 28.76^{\mathrm{b}}$ & $125.00 \pm 5.00^{\mathrm{c}}$ \\
Leaves cloves & $625.83 \pm 91.18^{\mathrm{c}}$ & $121.42 \pm 4.40^{\mathrm{c}}$ \\
Leaves nutmeg-Guinea pepper & $52.00 \pm 0.25^{\mathrm{a}}$ & $5.50 \pm 0.25^{\mathrm{a}}$ \\
Leaves nutmeg-cloves & $82.58 \pm 0.14^{\mathrm{a}}$ & $33.41 \pm 0.29^{\mathrm{b}}$ \\
Leaves Guinea pepper-cloves & $141.25 \pm 0.25^{\mathrm{b}}$ & $80.08 \pm 0.14^{\mathrm{c}}$ \\
Leaves nutmeg-Guinea pepper-cloves & $48.33 \pm 0.14^{\mathrm{a}}$ & $15.00 \pm 0.25^{\mathrm{a}}$ \\
\hline
\end{tabular}

In row, value with different letter differed significantly (Tukey test, $\mathrm{p} \leq 0.05$ )

\subsection{Antioxidant Activities in Spices and in Sweet Potato Leaves Steamed with and without Spices}

5.2.1 Free Radical Scavenging Activities and Anti-radical Power of Spices and Sweet Potato Leaves Steamed with and without Spices

Vitamin C, spices and sweet potato leaves steamed with and without spices DPPH free radical scavenging activities are presented in figures 1 and 2. These activities increase with concentrations and suggest a profound antioxidant activity (Bala et al., 2014). Vitamin C inhibitory concentration of 50\% DPPH $\left(\mathrm{IC}_{50}\right)$ is about 1.67 $\mu \mathrm{g} / \mathrm{ml}$. Among spices, cloves and Guinea pepper-cloves $\mathrm{IC}_{50}$ values $(0.45$ and $0.83 \mu \mathrm{g} / \mathrm{ml}$ respectively) do not differ significantly to that of vitamin $\mathrm{C}$ (reference), indicating a good antiradical activity and therefore an important antiradical power for cloves $(290.21 \mu \mathrm{mol} . \mathrm{ml} / \mu \mathrm{g})$ and Guinea pepper-cloves $(133.33 \mu \mathrm{mol} . \mathrm{ml} / \mu \mathrm{g})$ 
(Table 3). This is due to their total phenolic content and their positive synergetic effect. Indeed, Halvorsen et al. (2006) have indicated an antioxidant capacity of $125.55 \mathrm{mmol} / 100 \mathrm{~g}$ in cloves. According to Ghadermazi et al. (2017), cloves potential antioxidant activities could be attributed to higher content of phenolic component such as eugenol and eugenyl acetate and to their hydrogen donating ability by which they are potent free radical scavengers.

Steaming sweet potato leaves with spices improve the antiradical activity. Indeed, sweet potato leaves steamed without spices $\mathrm{IC}_{50}$ value $(7.83 \mu \mathrm{g} / \mathrm{ml})$ become $0.27 \mu \mathrm{g} / \mathrm{ml}$ with Guinea pepper and $0.50 \mu \mathrm{g} / \mathrm{ml}$ with cloves. The antiradical power in these sweet potato leaves steamed with Guinea pepper and cloves are respectively about 373.13 and $200.00 \mu \mathrm{mol} . \mathrm{ml} / \mu \mathrm{g}$. This could be due to their capacity to resist to thermal denaturation (Shobana $\&$ Naidu, 2000) and to the fact that some process like microwave, steaming and boiling increase antioxidant contents of food (Halvorsen et al., 2006). However, the 3 spices mixes (nutmeg-Guinea pepper-cloves) $\mathrm{IC}_{50}$ value is low $(16.00 \mu \mathrm{g} / \mathrm{ml})$ and produced an inhibition of DPPH free radical scavenging activities in steamed leaves. This is reflected by a low $\mathrm{IC}_{50}$ value in sweet potato leaves steamed with nutmeg-Guinea pepper-cloves $(23.17 \mu \mathrm{g} / \mathrm{ml})$ and a bad antiradical power of $4.32 \mu \mathrm{mol} . \mathrm{ml} / \mu \mathrm{g}$. Such result is probably due to their low total phenolic content. In fact, there is a positive correlation between phenolic compound and antioxidant capacity (Tangkanakul et al., 2009). This suggests that if total phenolic compounds are low, antioxidant capacity should be also low and vice versa.

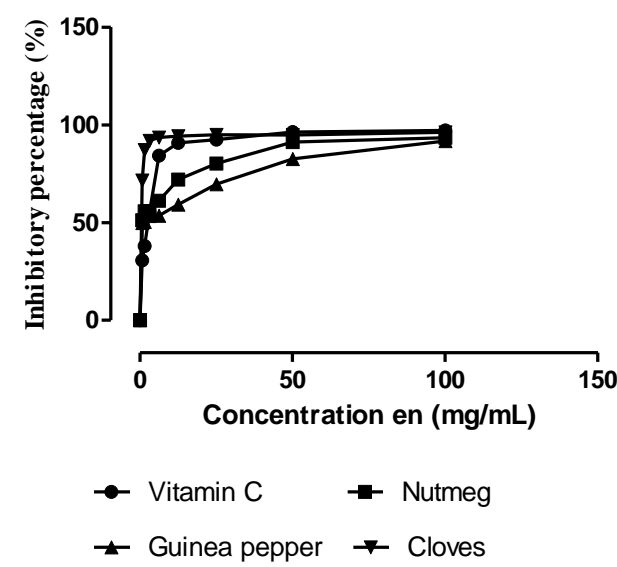

(a)

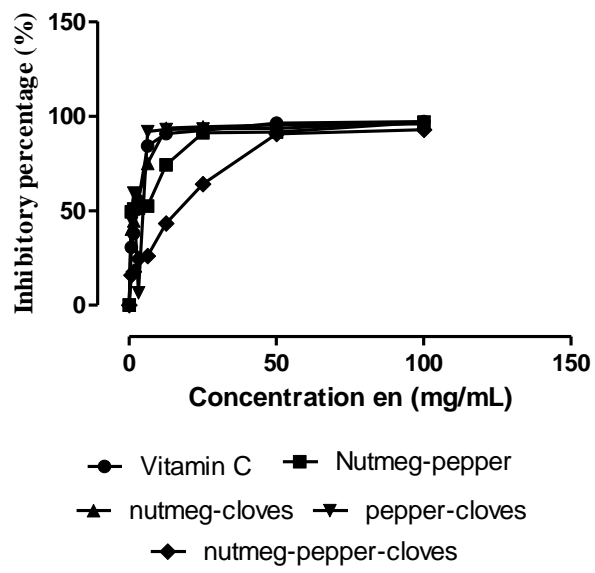

(b)

Figure 1. Evolution of antiradical activities of vitamin $\mathrm{C}$ and spices alone (a) and mixed spices (b)
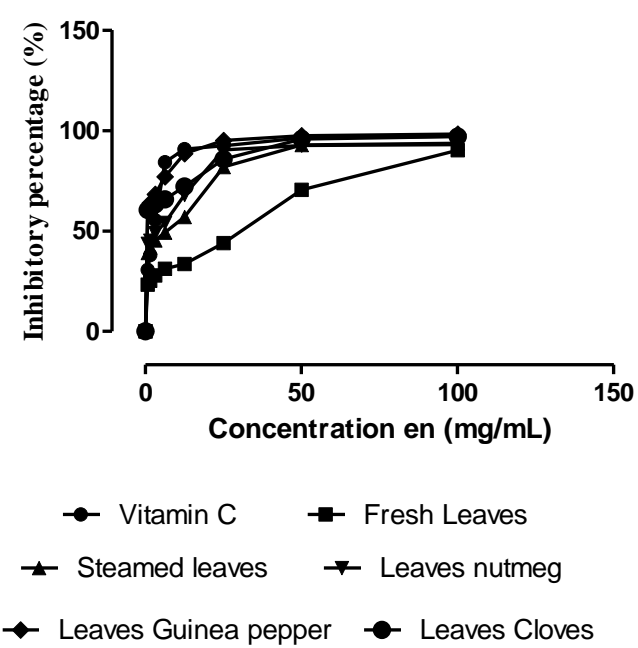

(a)
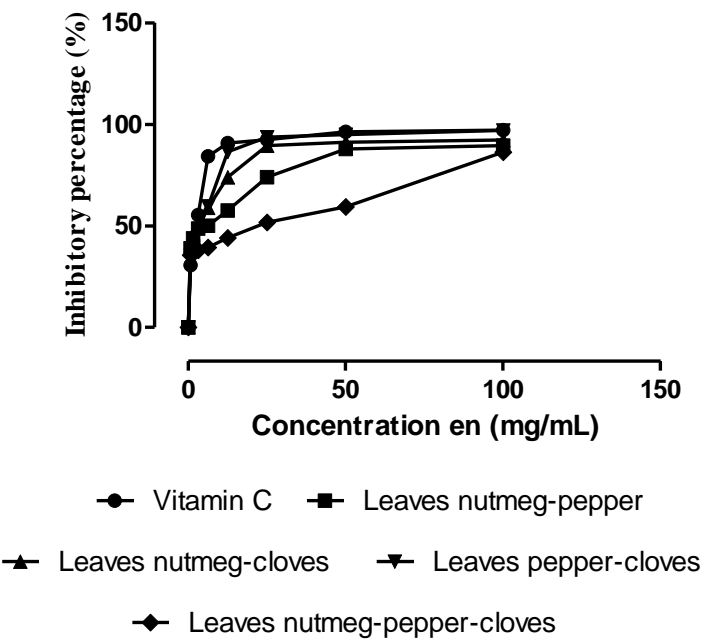

(b)

Figure 2. Evolution of antiradical activities of vitamin $\mathrm{C}$ and sweet potato leaves steamed with one spice (a) and sweet potato leaves steamed with mixed spices $(b)$ 
Table 3. Spices and sweet potato leaves steamed with and without spices average and standard deviation $\mathrm{IC}_{50}$ and antiradical power (ARP)

\begin{tabular}{lll}
\hline Spices and sweet potato leaves & IC50 $(\boldsymbol{\mu g} / \mathbf{m l})$ & ARP $(\boldsymbol{\mu m o l} . \mathbf{m l} / \boldsymbol{\mu g})$ \\
\hline *Vitamin C & $1.67 \pm 0.76^{\mathrm{a}}$ & $68.89 \pm 30.06^{\mathrm{c}}$ \\
Nutmeg & $1.50 \pm 0.50^{\mathrm{a}}$ & $72.22 \pm 25.46^{\mathrm{c}}$ \\
Guinea pepper & $5.12 \pm 2.93^{\mathrm{b}}$ & $23.39 \pm 10.10^{\mathrm{b}}$ \\
Cloves & $0.45 \pm 0.31^{\mathrm{a}}$ & $290.21 \pm 143.61^{\mathrm{d}}$ \\
Nutmeg-Guinea pepper & $4.83 \pm 1.44^{\mathrm{b}}$ & $21.79 \pm 5.55^{\mathrm{b}}$ \\
Nutmeg-cloves & $2.17 \pm 0.29^{\mathrm{b}}$ & $46.67 \pm 5.77^{\mathrm{c}}$ \\
Guinea pepper-cloves & $0.83 \pm 0.29^{\mathrm{a}}$ & $133.33 \pm 57.74^{\mathrm{d}}$ \\
Nutmeg-Guinea pepper-cloves & $16.00 \pm 0.50^{\mathrm{c}}$ & $6.25 \pm 0.20^{\mathrm{a}}$ \\
Fresh leaves & $31.00 \pm 1.80^{\mathrm{d}}$ & $3.23 \pm 0.19^{\mathrm{a}}$ \\
Steamed leaves & $7.83 \pm 0.76^{\mathrm{b}}$ & $12.85 \pm 1.30^{\mathrm{b}}$ \\
Leaves nutmeg & $4.17 \pm 0.58^{\mathrm{b}}$ & $24.34 \pm 3.67^{\mathrm{b}}$ \\
Leaves Guinea pepper & $0.27 \pm 0.01^{\mathrm{a}}$ & $373.13 \pm 0.10^{\mathrm{d}}$ \\
Leaves cloves & $0.50 \pm 0.01^{\mathrm{a}}$ & $200.00 \pm 0.06^{\mathrm{d}}$ \\
Leaves nutmeg-Guinea pepper & $7.67 \pm 1.15^{\mathrm{b}}$ & $13.23 \pm 1.83^{\mathrm{b}}$ \\
Leaves nutmeg-cloves & $3.17 \pm 0.76^{\mathrm{b}}$ & $32.78 \pm 7.52^{\mathrm{b}}$ \\
Leaves Guinea pepper-cloves & $3.50 \pm 0.50^{\mathrm{b}}$ & $28.97 \pm 4.18^{\mathrm{b}}$ \\
Leaves nutmeg-Guinea pepper-cloves & $23.17 \pm 2.93^{\mathrm{c}}$ & $4.36 \pm 0.52^{\mathrm{a}}$ \\
\hline
\end{tabular}

In row, value with different letter differed significantly (Dunnetts test, $\mathrm{p} \leq 0.05$ ).

*Vitamin C was chosen as control in Dunnetts test.

5.2.2 Lipid Peroxidation Inhibitory Activities of Spices and in Sweet Potato Leaves Steamed with and without Spices

Lipid peroxidation inhibitory activity of spices and sweet potatoes leaves steamed with and without spices are upper than that of standard (gallic acid) and increase with concentration $(200,600$ and $1000 \mu \mathrm{l} / \mathrm{ml})$ (Figure 3 and 4). Indeed, gallic acid lipid peroxidation activity vary from 65.32 to $74.69 \%$. Among spices, lipid peroxidation activity is important in nutmeg and varies from 90.00 to $93.54 \%$ (Figure 3). The fact that spices and sweet potato leaves steamed with and without spices have a lipid peroxidation inhibitory activity higher than that of gallic acid indicate their potentiality to inhibit linoleic acid lipid peroxidation. This is due to their flavonoids content which have the capacity to reduce peroxyl radicals by electrons transfer thanks to their low redox potential (Oktay et al., 2003; N'khili, 2009).

Steaming process improve fresh sweet potato leaves lipid peroxidation activity initially of $79.26 \%$ at $200 \mu \mathrm{l} / \mathrm{ml}$, to $85.02 \%$ also at $200 \mu \mathrm{l} / \mathrm{ml}$. Cloves and nutmeg-cloves also improve the lipid peroxidation rate. Indeed, in sweet potato leaves steamed with cloves, the lipid peroxidation activity varied from 86.46 to $97.34 \%$ and in sweet potato leaves steamed with nutmeg-cloves it varied from 88.38 to $93.38 \%$ (Figure 4). The improvement of lipid peroxidation rate during steaming could be due to this process. Moreover, Shobana \& Naidu (2000) have revealed that boiling increases the effect of spices extract on lipid peroxidation. 


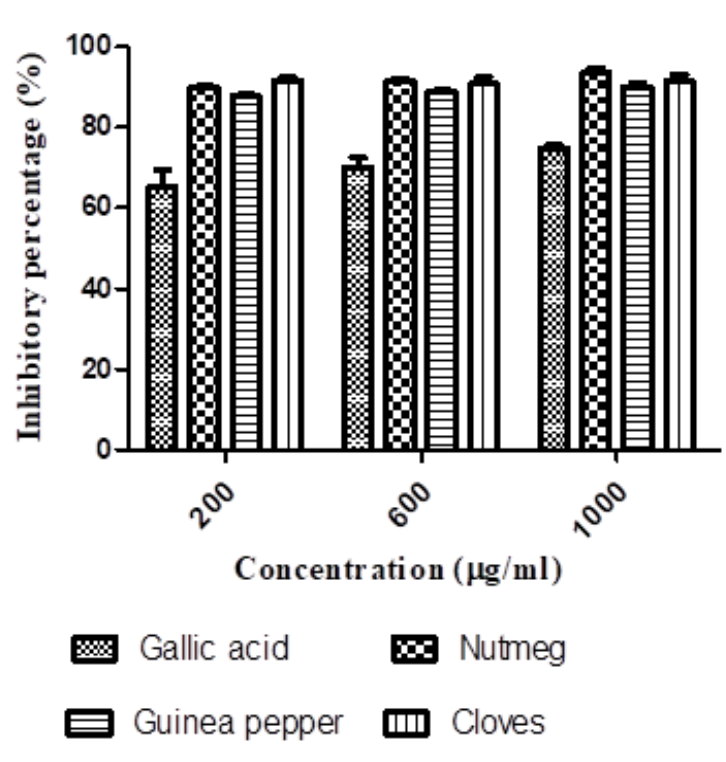

(a)
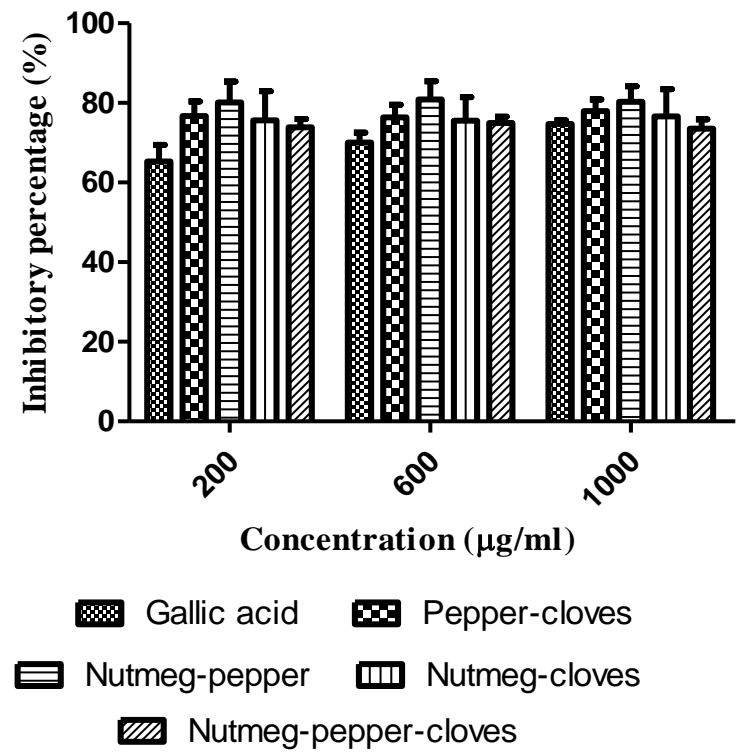

(b)

Figure 3. Evolution of lipid peroxidation inhibitory of gallic acid and spices alone (a) and mixed spices (b)
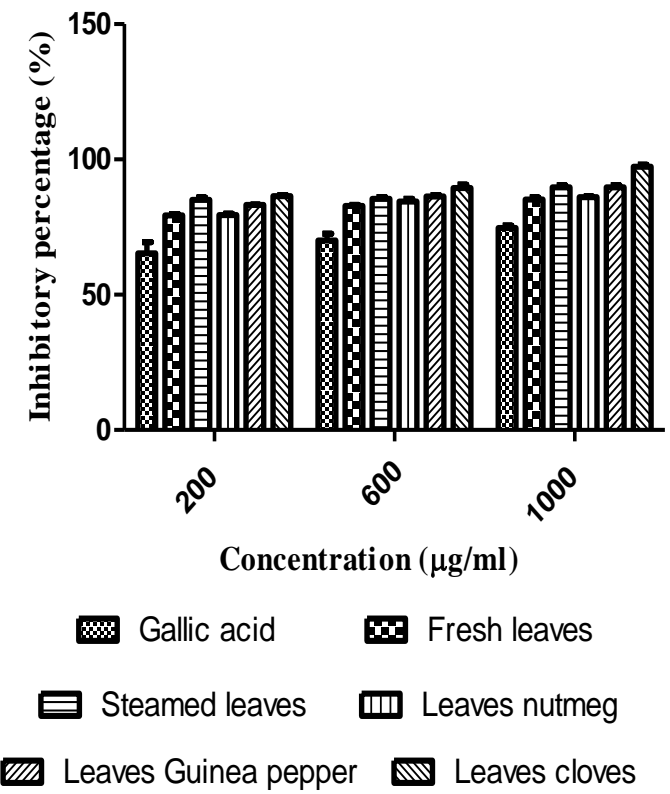

(a)

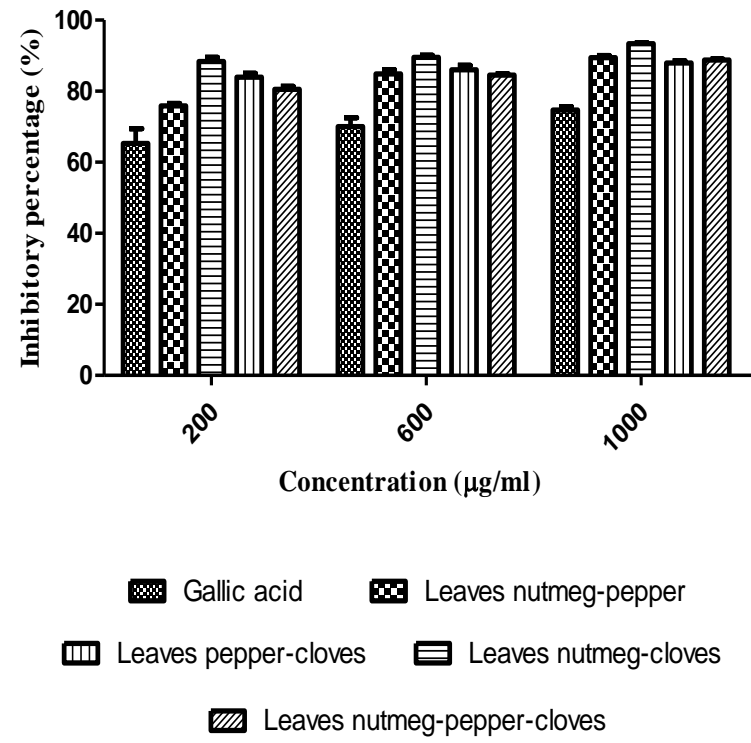

(b)

Figure 4. Evolution of lipid peroxidation inhibitory of gallic acid and sweet potato leaves steamed with one spice (a) and sweet potato leaves steamed with mixed spices (b)

\section{Conclusion}

This study had shown total phenolic compounds, flavonoids, and antioxidant potential capacities of spices and sweet potato leaves by their high antiradical power and lipid peroxidation inhibitory activities. With such capacities, spices, particularly cloves and Guinea pepper, contribute to enhance antioxidant activities during sweet potato leaves steaming. Spices used alone have a better action. While mixed, synergetic or inhibitory actions were observed. Indeed, Guinea pepper-cloves exhibit a synergetic effect improving total phenolic compound and antiradical activities. But inhibitory actions were revealed with nutmeg-Guinea pepper, nutmeg-cloves, and nutmeg-Guinea pepper-cloves mixes. Sweet potato leaves should be steamed with spices to 
increase their potential antioxidant activities. The best spices to be incorporated with sweet potato leaves are cloves used alone or mixed with Guinea pepper. This is grateful for households and will increase spices use while cooking leafy vegetables.

\section{Acknowledgments}

This study has been granted (E-3890-2) by COMESTECH and the International Foundation of Science (IFS). The authors thank these structures for their financial support. Thanks to colleagues of Pasteur Institute of Côte d'Ivoire and Nutrition and Food Security Laboratory of Nangui Abrogoua University for their contribution and technical support during the study.

\section{Conflict of interests}

The authors declare no conflict of interests.

\section{References}

Agbo, A. E., Gbogouri, A. G., N'Zi, J. C., Kouassi, K., Fondio, L., \& Kouamé, C. (2019). Evaluation des pertes en micronutriments et en oxalates au cours de la cuisson à l'eau et à la vapeur des feuilles d'épinard Malabar (Basella alba) et de célosie (Celosia argentea). Agronomie Africaine, 31(2), 100-110.

Agbo, A. E., Kouamé, C., Anin, A. L., Soro, L. C., N'zi, J.-C., Fondio, L., \& Gnakri, D. (2014). Seasonal variation in nutritional compositions of spider plant (Cleome gynandra L.) in South Côte d'Ivoire. International Journal of Agricultural Policy and Research, 2(11), 406-413.

Agbo, A. E., Méité, S., Traoré, S., Koffi, A. H., Assemand, E. F., \& Djaman, A. J. (2018). Antioxidant Potentialities of Black Nightshade and Sweet Potatoes Leaves Consumed in Côte d'Ivoire. American Journal of Food Nutrition, 6(1), 28-32. https://doi.org/10.12691/ajfn-6-1-5

Bala, I. M., Manigundan, K., Usha, J., \& Shanmuga, P. A. (2014). Antioxidant and Anti-proliferative activity of methanolic leaf extract of Eupatorium glandulosum L. International Journal of Advance Research, 2(7), 717-723.

Chang, C., Yang, M., Wen, H., \& Chern, J. (2002). Estimation of total flavonoid content in propolis by two complementary colorimetric methods. Journal of Food and Drug Analysis, 10, 178-182.

Chuah, A. M., Lee, Y-C., Yamaguchi, T., Takamura, H., Yin, L. J., \& Matoba, T. (2008). Effect of cooking on the antioxidant properties of colored peppers. Food Chemistry, 111, 20-28. https://doi.org/10.1016/j.foodchem.2008.03.022

García-Alonso, M., Pascual-Teresa, S., Santos-Buelga, C., \& Rivas-Gonzalo, J. C. (2004). Evaluation of the antioxidant properties of fruits. Food Chemistry, 84, 13-18. https://doi.org/10.1016/S0308-8146(03)00160-2

Gayathri, G. N., Platel, K., Prakash, J., \& Srinivasan, K. (2004). Influence of antioxidant spices on the retention of $\beta$-carotene in vegetables during domestic cooking processes. Food Chemistry, 84, 35-43. https://doi.org/10.1016/S0308-8146(03)00164-X

Ghadermazi, R., Keramat, J., \& Goli, S. A. H. (2017). Antioxidant activity of clove (Eugenia caryophyllata Thunb), oregano (Oringanum vulgare L) and sage (Salvia officinalis L) essential oils in various model systems. International Food Research Journal, 24(4), 1628-1635.

Gokoglu, N., Yerlikaya, P., \& Cengiz, E. (2004). Effects of cooking methods on the proximate composition and mineral contents of rainbow trout. Food Chemistry, 84, 19-22. https://doi.org/10.1016/S0308-8146(03)00161-4

Grela, E. R., \& Pietrzak, K. (2014). Production Technology, Chemical Composition and Use of Alfalfa Protein-Xanthophyll Concentrate as Dietary Supplement. Journal of Food Process and Technology, 5, 373. https://doi.org/10.4172/2157-7110.1000373

Halvorsen, B. L., Carlsen, M. H., Phillips, K. M., Bøhn, S. K., Holte, K., Jacobs Jr, D. R., \& Blomhoff, R. (2006). Content of redox-active compounds (ie, antioxidants) in foods consumed in the United States. American Journal ol Clinic Nutrition, 84, 95-135. https://doi.org/10.1093/ajen/84.1.95

Johnson, M., \& Pace, R. (2010). Sweet potato leaves: properties and synergistic interactions that promote health and prevent diseasenure. Nutrition Reviews, 68(10), 604-615. https://doi.org/10.1111/j.1753-4887.2010.00320.x

Kroyer, G. T. (2004). Red clover extract as antioxidant active and functional food ingredient. Innovative Food Science and Emerging Technologies, 5, 101-105. https://doi.org/10.1016 / S1466-8564 (03) 00040-7 
Lee, C. Y., Sharma, A., Cheong, J. E., \& Nelson, J. L. (2009). Synthesis and antioxidant properties of dendritic polyphenols. Bioorganic and Medicinal Chemistry Letters, 19, 6326-6330. https://doi.org/10.1016/j.bmcl.2009.09.088

Mc Donald, S., Prenzler, P. D., Autolovich, M., \& Robards, K. (2001). Phenolic content and antioxidant activity of olive extracts. Food Chemistry, 73, 73-84. https://doi.org/10.1016/j.bmcl.2009.09.088

Mibei, E. K., Ojijo, N. K. O., Karanja, S. M., \& Kinyua, J. K. (2012). Phytochemical and antioxidant analysis of methanolic extracts of four african indigenous leafy vegetables". Annals. Food Science and Technology, 13(1), 37-42.

N'khili, E. Z. (2009). Polyphénols de l'alimentation: extraction, interaction avec les ions du fer et du cuivre, oxydation et pouvoir antioxydant. Thèse de doctorat, Montpellier, pp. 306.

Oboh, G., \& Rocha, J. B. (2007). Polyphenols in red pepper and their protective effect on some pro-oxidants induced lipid peroxidation in brain and liver. European Food Research and Technology, 225, 239-247. https://doi.org/10.1007/s00217-006-0410-1

Oktay, M., Gulcin, I., \& Kufrevioglu, O. I. (2003). Determination of in vitro antioxidant activity of fennel (Foeniculum vulgare) seed extracts. Lebensmittel-Wissenchaft und Technologie, 36, 263-271. https://doi.org/10.1016/S0023-6438(02)00226-8

Oulai, P. D., Zoué, L. T., \& Niamké, S. (2015). Evaluation of Nutritive and Antioxidant Properties of Blanched Leafy Vegetables Consumed in Northern Côte d'Ivoire. Polish Journal of Food and Nutrition Sciences, 65(1), 31-38. https://doi.org/10.1515/pjfns-2015-0003

Parejo, I., Codina, C., Petrakis, C., \& Kefalas, P. (2000). Evaluation of scavenging activity assessed by Co (II)/EDTA-induced luminol chemilunescence and DDPH (2,2-diphenyl-1-pycryl-hydrazyl) free radical assay. Journal of Pharmacological and Toxicological Methods, 44, 507-512. https://doi.org/10.1016/S1056-8719(01)00110-1

Shobana, S., \& Naidu, K. A. (2000). Antioxidant activity of selected Indian spices. Prostaglandins, Leukotrienes and Essential Fatty Acids, 62(2), 107-110. https://doi.org/10.1054/plef.1999.0128

Su, X., Griffin, J., Xu, J., Ouyang P., Zhao, Z., \& Wang, W. (2019). Identification and quantification of anthocyanins in purple-fleshed sweet potato leaves. Heliyon. pp. 1-6. https://doi.org/10.1016/j.heliyon.2019.e01964

Sun, H., Mu, T., Xi, L., Zhang, M., \& Chen, J. (2014). Sweet potato (Ipomoea batatas L.) leaves as nutritional and functional foods. Food Chemistry, 156, 380-389. https://doi.org/10.1016/j.foodchem.2014.01.079

Tang, Y., Cai, W., \& Xu, B. (2015). Profile of phenolics, carotenoids and antioxidative capacities of thermal processed white, yellow, orange, and purple sweet potatoes grown in Guilin, China. Food science and Human Wellness, 4, 123-132. https://doi.org/10.1016/j.fshw.2015.07.003

Tangkanakul, P., Auttaviboonkul, P., Niyomwit, B., Lowvitoon, N., Charoenthamawat, P., \& Trakoontivakorn, G. (2009). Antioxidant capacity, total phenolic content and nutritional composition of Asian foods after thermal processing. International Food Research Journal, 16, 571-580.

Viuda-Martos, M., Navajas, R. Y., Zapata, S. E., Fernández-López, J., \& Pérez-Álvarez, J. (2010). Activité antioxydante des huiles essentielles de cinq plantes à épices largement utilisées dans un régime méditerranéen. Flavor and flagrance journal, 25, 13-19. https://doi.org/10.1002/ffj.1951

Vyas, S., Collin, S., Bertin, E., Davys, G., \& Mathur, B. (2009). Leaf concentrate ace adolescent year alternate to iron and folic acid supplements for anemic girls: randomized controlled trial in India. Public health Nutrition, pp. 1-6. https://doi.org/10.1017 / S1368980009991224

Zoro, A. F., Zoué, L. T., Bédikou, M. E., Kra, S. A., \& Niamké, S. L. (2014). Effect of cooking on nutritive and antioxidant characteristics of leafy vegetables consumed in Western Côte d'Ivoire. Archives of Applied Sciences Research, 6(4), 114-123.

\section{Copyrights}

Copyright for this article is retained by the author(s), with first publication rights granted to the journal.

This is an open-access article distributed under the terms and conditions of the Creative Commons Attribution license (http://creativecommons.org/licenses/by/4.0/). 